УДК 622.7

\title{
Extraction Colloidal Gold from Solutions
}

\author{
Aleksandra V. Romanenko*a, \\ Victor I. Bragina, Irina I. Baksheyeva ${ }^{b}$, \\ Victor I. Rostovtsev ${ }^{\text {b }}$ and Anatoliy M. Zhizhayev \\ ${ }^{a}$ Siberian Federal University \\ 79 Svobodny, Krasnoyarsk, 660041, Russia \\ ${ }^{b}$ Institute of mining $S B R A S$ \\ 54 Krasniy, Novosibirsk, 630091, Russia \\ 'Institute of Chemistry and Chemical Technology SB RAS \\ FRC "Krasnoyarsk Science Center SB RAS" \\ 50/24 Akademgorodok, Krasnoyarsk, 660036, Russia
}

Received 18.07.2016, received in revised form 26.09.2016, accepted 10.10.2016

The article discusses a gold extraction method based on the use dihydrothioctic acid as the dispersing reagent. The possible use cases dihydrothioctic acid and optimal processing conditions are looked in the article.

Keywords: nanoparticles, gold, colloid functionalization, finely impregnated ores, refractory gold ores, magnetic separation, magnetic colloid.

DOI: 10.17516/1998-2836-2016-9-4-504-514.

(c) Siberian Federal University. All rights reserved

* Corresponding author E-mail address: ali4ka1993@1ist.ru 


\title{
Извлечение коллоидного золота из растворов
}

\author{
А.В. Романенко ${ }^{\mathrm{a}}$ В.И. Брагин ${ }^{\mathrm{a}}$, \\ И.И. Бакшеева ${ }^{\tilde{\sigma}}$ В.И. Ростовцев ${ }^{\tilde{0}}$, А.М. Жижаевв \\ ${ }^{a}$ Сибирский федеральный университет \\ Россия, 660041, Красноярск, пр. Свободный, 79 \\ ${ }^{6}$ Институт горного дела СО РАН \\ Россия,630091, Новосибирск, Красный пр., 54 \\ ${ }^{6}$ Институт химии и химической технологии СО РАН \\ ФИЦ «Красноярский научный центр СО РАН» \\ Россия, 660036, Красноярск, Академгородок, 50/24
}

В статье обсуждается метод извлечения золота из растворов, основанный на применении дигидротиоктовой кислоты в качестве диспергирующего реагента. Рассмотрены возможные варианты использования дигидротиоктовой кислоты. Определены оптимальные условия ведения прочесса.

Ключевые слова: наночастицы, золото, функиионализация коллоида, тонковкрапленные руды, руды с упорным золотом, магнитная сепарация, магнитный коллоид.

\section{Introduction}

Extraction hydrometallurgical methods of nonferrous and noble metals from secondary raw and technogenic oresare becoming more widespread with the decline of resource quality. Currently, great attention has been the technology to effectively extract metal ions from industrial solutions and create circular water systems, preventing detrimental effects on the environment. Extraction of nonferrous and noble metals from processingmedium is essential whether protection the environment ormetals value $[1,2]$. Consequently, investigations on recycling processing medium and extracted components utilization are actual scientific and practical problem.

Hydrometallurgy is the most widely used in the gold extraction.

Gold mining requires large areas and great many of hazardous chemical.Cyanidationis the most extended method of gold recovery by changing over to the solution liquid phase, known as MacArthurForrest process [3].

At present, there are two methods of gold cyanidationin mining: heap leaching and tankleaching wherehead ore is mixed in theleaching seti. etank containing cyanides.

It's quite time-consuming to output gold by cyanidation method. The entire ore technological processincludes such operations as filtration, sedimentation and decantation. Improper technology use leads to unprofitability, it means that the gold cyanidation should be used in large production scale, for example, in the USA and Russia.

Gold recovery by cyanidation is limited to mineral composition of ores. The method is not applicable if the ore contains large number of arsenides and sulphides, as cyanides react with these substances. Mined gold contains various impurities, so before the cyanide leachingthe ore is subjected to special high purity processes, which are performed at refineries.

$$
-505-
$$


They use extraction, adsorption and ion exchange for the extraction of metals from the productive and circulating hydrometallurgical solutions. So, metal adsorption to activated carbon is the most frequently used to the gold recovery from cyanide solutions. Sorption is carried out in dynamic conditions, flowing gold-bearing solution consistently through 3-4 vertical columns filled with granular active coal and grains size are about $1 \mathrm{~mm}$. The coal is intermittently loaded from column to column toward the movement of the solution. From the first column (by the solution direction) saturated precious metals coal is discharged and the regenerated sorbent is loaded to the last column. Rich coal containing 2-5 kg/t of gold, is the regeneration [4]. Also the metal sorption isused onto ion exchange resin. The advantages of ion exchange resinsin comparison with the activated carbon are: a higher degree of the resins saturation up to $20-30 \mathrm{~kg} / \mathrm{ton}$, compared with 3-5 kg/ton for coal; a significant rate of reaction and gold recovery from solution, as a result is reduction of the process 3-5 times also decrease of the sorbent weight and volume of the sorbent equipment; the higher recovery rate from pregnant solutions (the residual contents in solutions of $0.01-0.03 \mathrm{mg} / 1$ for resins compared to $0.1 \mathrm{mg} / \mathrm{l}$ for coal) [5].

Along with these classical methods there areother ways of extracting gold from reusable solutions that are based on ideas and approaches from the rapidly developing field of science - nanotechnology.

The nanotechnology development leads to becoming of a variety of materials that contain nanoscale particles. Nanostructured magnetic materials can be divided into nanoheterostructure, nanoparticles and magnetic quantum dots [6]. In the modern world industrial production of various nanoparticles is about of hundreds of thousands of tons. Being in the nanoscale state, many substances acquire new properties and become biologically very active [7]. This opens up new opportunities for the use of nanomaterials in biomedicine, pharmacology, food production, and in environmental and agricultural industry, in the steel industry [8-10]. The most well-known nanoparticles are particles of carbon (nanotubes, fullerenes, graphene), silica nanoparticles, gold, silver as well as titanium dioxide and zinc oxide [11-13].

The modern trend towards miniaturization has shown if you take a very small particle of this substance the substance may have completely new properties. Particle sizes from 1 to 100 nanometers are called nanoparticles.

Among the most promising magnetic materials should emphasize the nanostructured composites in form of layers and colloidal particles, which are synthesized by chemical methods. Such materials can be used in electronics and biomedicine as electromagnetic energy absorbers, contrast agents for magnetic resonance tomography and medicaments for hyperthemictherapy [14].

Currently, nanoparticles are the basis of many new technological processes, including those based on using the adsorption phenomenon, which can be conveniently adjusted by changing the composition of active groups on the surface. It's convenient to carry out such processing with the particles that are easily extracted from solution, for example magnetic particles.

Magnetic nanoparticles are found in many biological systems and are widely spread in nature. Magnetic nanomaterials are used in pharmacology, ecology, in systems of recording and storing information, in magnetic cooling systems, in new permanent magnets, and a great application in biomedicine $[15,16]$. We can say that biomedicine has become one of the main directions of applied research infield of magnetic nanomaterials, particularly iron oxides. Specific diagnostic and therapeutic applications appear in the scientific literature for more than 20 years [17, 18]. 
Magnetic nanoparticles have also found application in mineral processing, they are used in gravity (ferrohydrostaticseparator), thickening (flocculation with polymers), in flotation, they are also used as colloidal and polymeric regulators [19].

Magnetic properties of nanoparticles are determined by a large number of factors: the type of crystal lattice and its defects, chemical composition, size and shape of the particles. Within certain limits it is possible to control the magnetic characteristics of materials, changing shape, size, structure and composition of nanoparticles.

The main colloid-chemical properties, determining the conditions for the use of magnetic nanoparticles for the purpose, is the aggregative stability of the colloidal systems in combination with high dispersion of the magnetic phase.

Nanostructured magnetic materials can be obtained through chemical synthesis, which is devoted to the consideration of a number of works [20-23]. The most common methods are:

- electrolesscodepositionfrom precursor solutions;

- sol-gel method, synthesis in reversed micelles;

- synthesis in the films the Langmuir-Blodgett and adsorbed layers;

- recover metal-containing compounds (for making metal nanoparticles, that can be oxidized in a special way, for example, for the preparation of colloidal iron oxide particles solutions);

- high temperature pyrolysis of organometallic compounds.

Some methods can be directly used to obtain the final nanocomposite (sol-gel process, the method of the Langmuir - Blodgett). Usually if other methods are involved, nanosized magnetic particles should be stabilized in liquid or solid organic matrix or inorganic materials [24-26].

Chemical methods are most popular in the preparation of magnetic liquidsandhave a wide range of materials for various purposes. The magnetic colloids is described in application for sealing in mechanism cylinders, as the magnetic colloids are a cooling agent in the composition of friction materials to local thermal effect at the pathology place and to weld tissues in the medicine [26].

Now the most attention is devoted tonanomaterials based on iron oxides. It is explained the versatility of their properties: as a natural metabolite, superparamagnetic magnetite nanoparticles have low toxicity [27, 28] and are capable of magnetotaxis in an external field [29], and are used for hyperthermia because of the low resistivity [30,31].

Special interest in nanomaterials are largely due to the practical significance of the research. Concerning about nanomaterials is much more compared to other magnetic materials, looking through the articles over the past few years.

Thus, there is sufficient experience in the use of magnetic colloids to extract particles of different nature in the researches; methods have been developed to control the reaction of colloids with surfaces, in order to control functionalization and stabilization. However, the use of these results for colloidal noble metal particles, particularly gold particles, requires specification for these processes.

\section{The idea}

Method of extraction of colloidal gold from solution involves the use of reagent, which has at least two active groups with separated by sufficiently long and flexible bridge. One group provides the bonding of the reagent to the colloid, the second - functionalization. It is convenient to use the reduced form of thioctic (lipoic) acid as the reagent. 
The chemical reduction of thioctic (lipoic) acid can be described by the general formula (1):

The Fig. 1 shows the molecule geometry of the thioctic (lipoic) acid in the crystal. During reduction process the connection S1-S2 is broken, resulting two active sulfhydryl groups are formed that can be

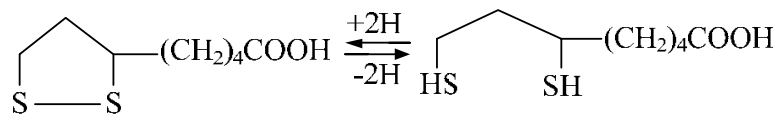

lipoic acid (oxidized form)

dihydrolipoic acid (reduced form)

fastened to the gold.

In this paper, we investigate the possibility of applying dihydrothioctic acid in two ways:

1. Application as a collector of gold;

2. Application for dispersion of colloidal gold.

Fig. 2 shows the dihydrothioctic acid functions.

1. Dihydrothioctic acid is proposed to use as a collector of gold, the proposed essence is as follows: it is proposed to use magnetic nanoparticles of iron oxides to extract the metals from solutions; the magnetic nanoparticles are functionalized by sulfhydryl active groups dihydrothioctic acid. The proposed method is that a magnetic nanoparticle is overlaid with reagent coat (dihydrothioctic acid) which is fixed on the particle surface with the active carboxyl group; the other end functionalized molecule has a sulfhydryl group that can bond gold. By mixing the colloids adhere to the mineral surface that can be separated using magnetic beneficiation methods. In this way it is possible to extract not only dissolved gold, but also colloidal.

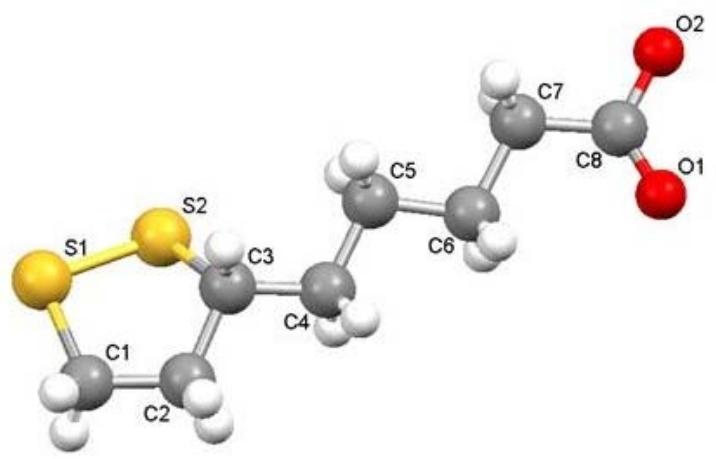

Fig.1. Molecule geometry of the thioctic (lipoic) acid in the crystal

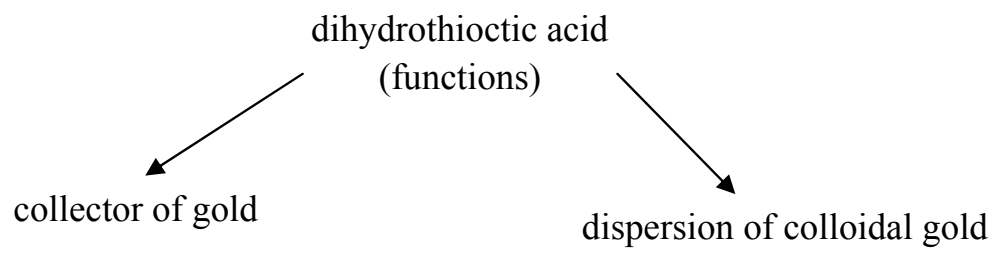

Fig. 2. Dihydrothioctic acid functions 
The greatest magnetic nanoparticles efficiency is provided by chemical functionalization of the surface, which increases sorption activity and affinity to the extracted metal. With such functionalization the greatest flexibility is provided with a colloidal particle size. In this case, the magnetic colloidal particles can becarriers, if there areions sorption or small molecules; or perform the magnetic function of the agent, which is fixed on the surface of large particles, giving them magnetic properties. Metal sorption is carried out by small dosages of magnetic colloid, which is then removed by magnetic separation. Methods of extraction vary depending on the required magnetic field intensity.

2. Colloidal gold is often contained in ores with dihydrothioctic acid. It is proposed to transform it to the dissolved state, and then to extract from a solution with magnetic nanoparticles.

Theinvestigation is devoted to laerning the possibility of applying dihydrothioctic acid as dispersing colloidal gold.

\section{Characterization of colloid gold in dihydrothioctic acid solution}

For the investigation dihydrothioctic acidwas obtained by the following procedure: thioctic acid $\left(\mathrm{C}_{8} \mathrm{H}_{14} \mathrm{O}_{2} \mathrm{~S}_{2}\right)(12.2 \mathrm{~g}, 59 \mathrm{mmol})$ was dissolved in $250 \mathrm{ml} 0.25 \mathrm{M} \mathrm{NaHCO}_{3}$ solution and cooled to $0{ }^{\circ} \mathrm{C}$. It was added NaBH4 $(9.0 \mathrm{~g}, 238 \mathrm{mmol})$ and the temperature was maintained below $4{ }^{\circ} \mathrm{C}$ under stirring for 2 hours. The mixture was acidified using $6 \mathrm{M} \mathrm{HCl}$ to $\mathrm{pH}=1$ and extracted with toluene and then filtered.

The possibility of using dihydrothioctic acidfor dispersing colloidal gold was tested on real ore. Chemical gold precipitatewas used, as the source of ore. A sample of ore was treated with $4 \%$ solution dihydrothioctic acid.

As a result of processing chemical gold precipitate with dihydrothioctic acid, a solution was obtained which gives the Tyndale cone (Fig. 3).

Tyndale effect is light scattering while passing the light beam through an optically inhomogeneous medium. It is usually seen as a luminous cone (Tyndale cone), that is visible on a dark background. It is indicative for solutions of colloidal systems (for example, metal sols, diluted latex, tobacco smoke), where the particles and environment differ in refractive index. The Tyndale effect is base for a number of optical methods for the determination of the size, shape and concentration of colloidal particles and macromolecules [18].

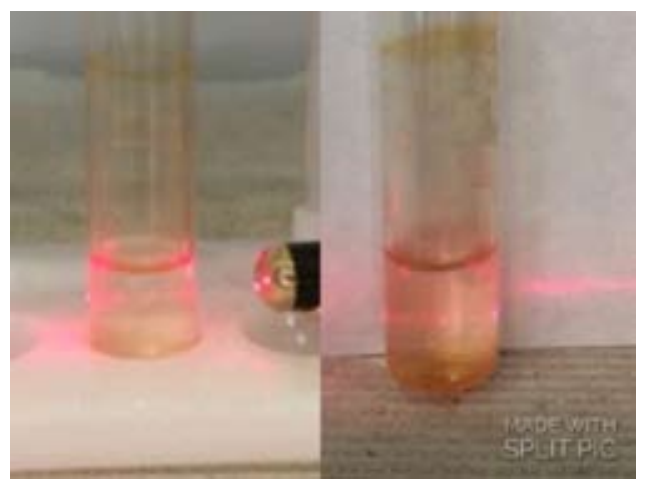

Fig. 3. Tyndale cone 
Available Tyndale cone suggests that dihydrothioctic acid is a reagent that is able to transform the colloidal gold in solution.

The method of photon-correlation spectroscopy (DLS) (Malvern Zetasizer Nano ZS, Malvern Instruments Ltd, UK) has established that the solution contains gold particles, whichhydrodynamic radius is not more than $350-1000 \mathrm{~nm}$ of.

The solution that is obtained after the treatment of gold with dihydrothioctic acid was studied by transmission electron microscopy (Hitachi HT7700, Japan). The preparation was carried out as follows: surface of the object stage was processed with a colloidal solution. The treated surface was washed with distilled water and dried in vacuum. It was observed precipitate colloids.

The results are presented in Fig. 4.

As can be seen from the photographs, different sizes of $\mathrm{Au}$ aggregates are observed in the dihydrothioctic acid solution. It is determined that the true sizes of gold nanoparticles are $5-20 \mathrm{~nm}$.

A day later a precipitate was formed at the bottom of the test tube, where gold was treated with dihydrothioctic acid. The precipitate had been studied on the tabletop electron microscope Hitachi TM 3000. Sample preparation was carried out as follows: conductive carbon tape wasdeposited on the stage surface, and then it was covered with a thin coat of the test sample.
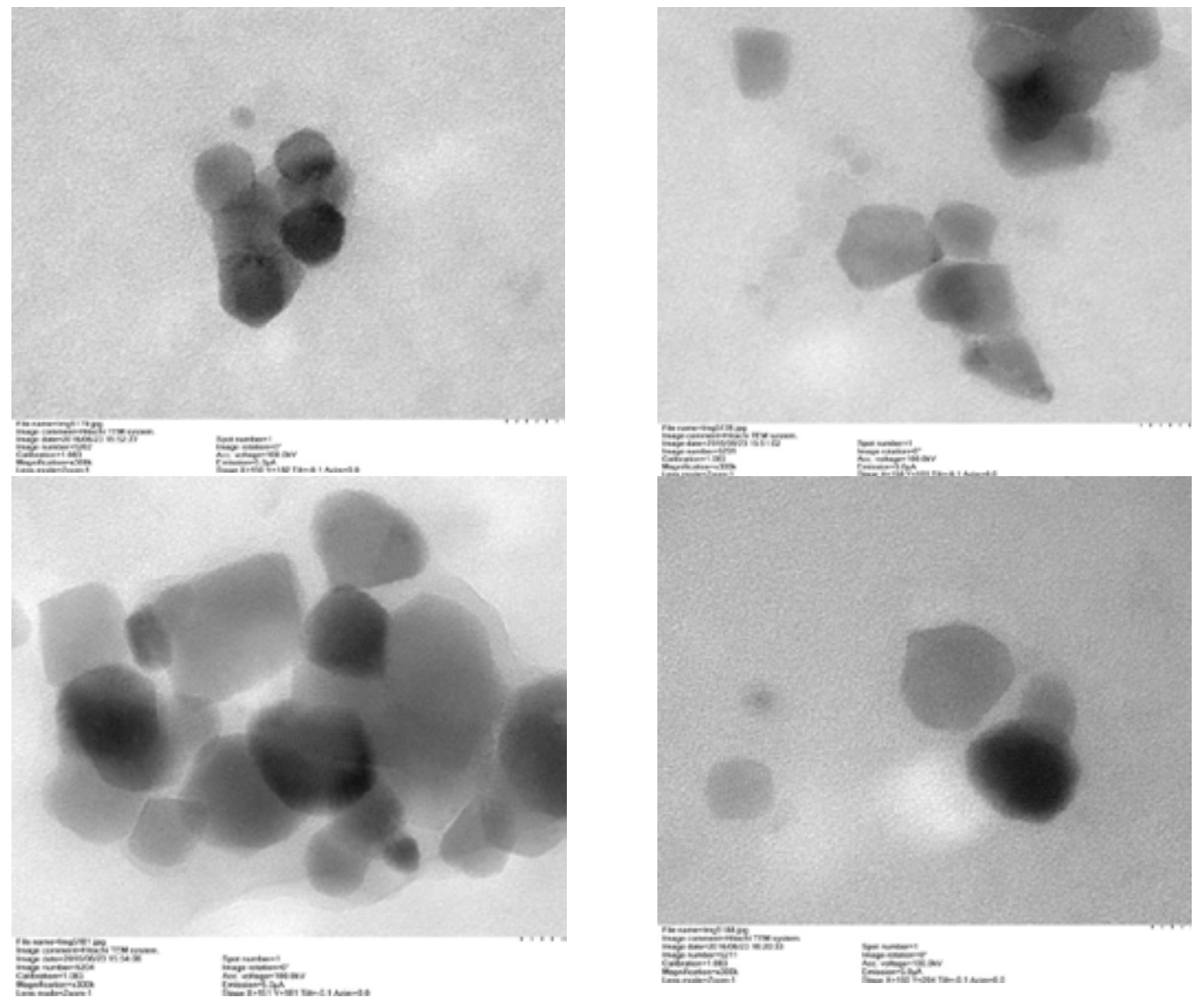

Fig. 4. Electron microscopy photographs of gold nanoparticles in dihydrothioctic acid solution 
The results are presented in Fig. 5-7.

Fig. 5 clearly shows that the precipitate is presented by the large agglomerate, has a fine structure, and encapsulates a large number of small particles and aggregates. The basic composition has shown
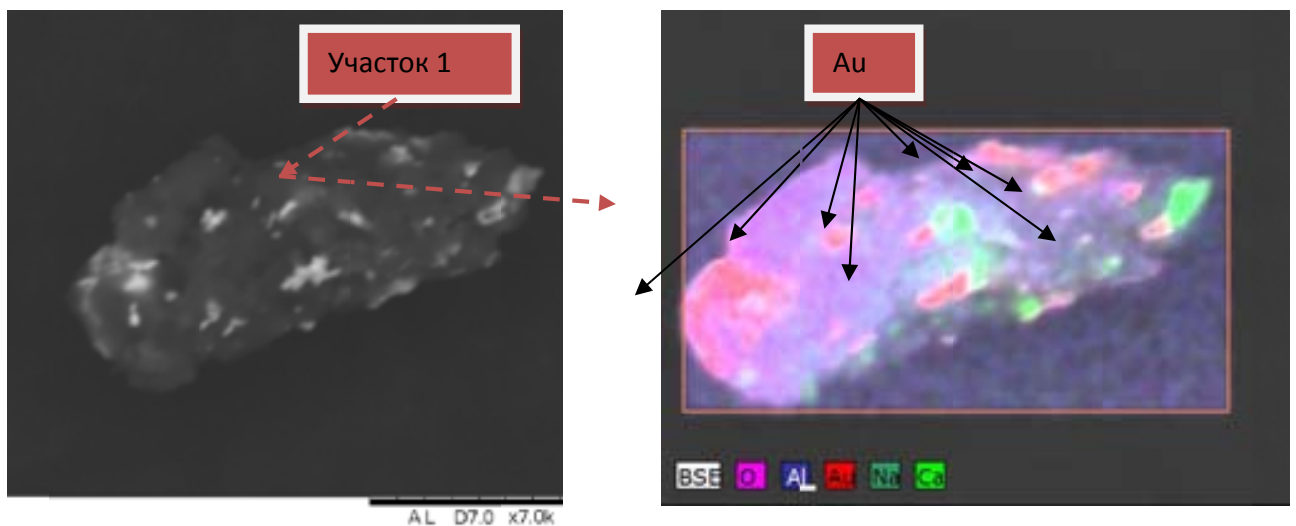

Fig. 5. Precipitate microphotographs

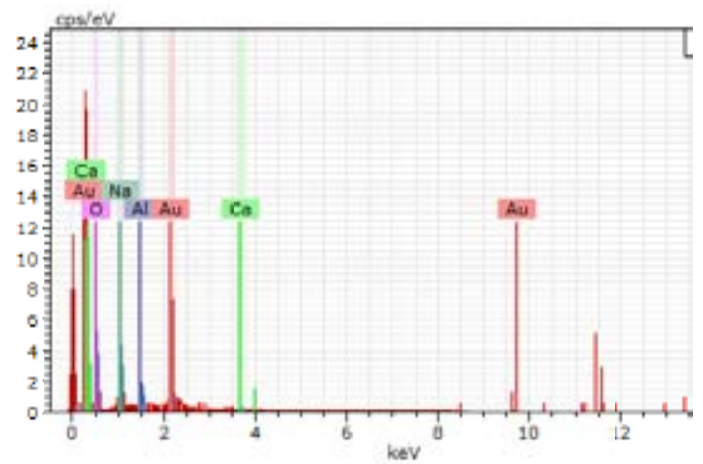

Fig. 6. Basic composition of the plot 1, Fig. 5
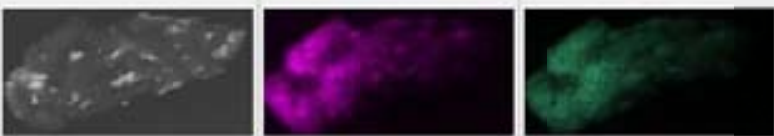

QSE

$0 \cdot k A$

Nara
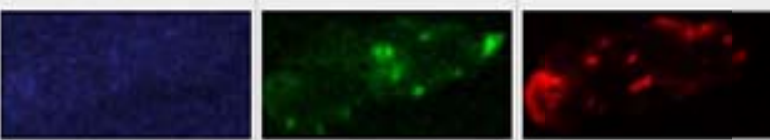

Al.

Cakn

Acemen

Fig.7. Basicchartof the plot 1, Fig. 5 
that the aggregates havegold micronic with organic impurities and decomposition products. The reason is oxidation dihydrothioctic to thioctic acid.

\section{Conclusion}

The proposed method of colloidal gold extraction from solutions is based on approaches developed in the last decade in various fields of nanotechnologies - biomedicine, self-assembly of nanostructures, etc. The method involves the use of reagent, which has at least two active groups with separated by sufficiently long and flexible bridge. One group provides the bonding of the reagent to the colloid, the second - functionalization. It is convenient to use the reduced form of thioctic (lipoic) acid as the reagent.

It is proposed application variants ofdihydrothioctic acid - use as a gold collector and dispersion of colloidal gold.

In terms of chemicalgold sedimenthas demonstrated the possibility of transform of colloidal gold to solution after treatment with $4 \%$ solution dihydrothioctic acid.

Further methods development of colloidal gold extraction to the solution will allow to develop technological options method, to study the particularity of its application and to obtain practical results: reducing of the cost beneficiation, improvement of technological parameters, increasingthe level of ecological safety.

The work is accomplished at the expense of the Russian scientific Fund ( No. 15-17-10017).

\section{References}

1. Варламова И.А., Гиревая Х.Я., Калугина Н.Л., Куликова Т.М., Медяник Н.Л. Физикохимические закономерности извлечения тяжелых металлов из техногенных гидроминеральных месторождений. М.: МиниТип, 2010. 246 с. [Varlamova I. A., Kettlebell, H. I., Kalugina N. L., Kulikova T. M., Medyanik N. L. Physico - chemical principles of extraction of heavy metals from technogenic hydromineral deposits. Magnitogorsk, Minitype, 2010, 246 p. (in Russ.)]

2. Медяник Н.Л., Гиревая Х.Я. Извлечениеионовмедиизсточныхводспомощьюосадителе й-восстановителей. Вестник Магнитогорского государственного технического университета им. Г.И. Носова. 2007. № 1. С. 113-114. [MedyanikN. L., Girevaya H. I. Extractionofcopperionsfrom wastewaterusingprecipitating-reducingagents. Bulletin of Magnitogorsk state technical University. G. I. Nosova. - 2007. - № 1. 113-114 p. (inRuss.)]

3. Минеев Г.Г, Панченко А.Ф. Растворители золота и серебра в гидрометаллургии. М.: Металлургия, 1994. 241 с. [Mineev G. G, Panchenko A. F. Solvents of gold and silver in hydrometallurgy. Moscow, Metallurgy, 1994. 241 p. (in Russ.)]

4. Минеев Г.Г. Биометаллургия золота. М.: Металлургия, 1989.147 с. [Mineev G. G. Biometallurgy gold. Moscow, Metallurgy, 1989.147 p. (in Russ.)]

5. Черняк А.С., Овчинникова О.В. Вторичные ионообменные явления в процессах выщелачивания золота и серебра. М.: Наука, 1980. 189 с. [Chernyak, A. S., Ovchinnikov O. V. Secondary ion-exchange phenomena in the processes of leaching of gold and silver. Magnitogorsk, Nauka, 1980. 189 p. (in Russ.)]

6. W.J.R. Santos, P.R. Lima, C.R.T. Tarley, L.T. Kubota, J. Braz. Chem. Soc. 20 (2009) 820. 
7. Widder K. J., Senyei A. E., Scarpelli D. G. Proc. of The Society for Experimental Biology and Medicine, 1978, № 58., P. 141-146.

8. S.Yean, L. Cong, C.T. Yavuz, J.T. Mayo, W.W. Yu, A.T. Kan, V.L. Colvin, M.B. Tomson, Effect of magnetite particle size on adsorption and desorption of arsenite and arsenate, Journal of Materials Research, 20 (12), 3255-3264 (2005).

9. Urbain, and W. R. Stemen, U.S. Patent No. 2,232,294, Feb. 18, 1941.

10. B. A. Bolto, D. R. Dixon, R. J. Eldridge, E. A. Swinton, D. E. Weiss, D. Willis, H. A. J. Battaerd, and P. H. Young, Journal of Polymer Science, Symp. No. 49, 211, 1975.

11. Arruebo M., Fernandez-Pacheco R., Irusta S. et al. Sustained release of doxorubicin from zeolite-magnetite nanocomposites prepared by mechanical activation // Nanotechnology; 2006; 17: 4057- 4064 .

12. Huang X., Jain P.K., El-Sayed I.H. et al. Gold nanoparticles: interesting optical properties and recent applications in cancer diagnostics and therapy.// Nanomedicine. 2007. V.2(5). P.681.

13. Stratmeyer M.E., Goering P.L., Hitchins V.M. et al. What we know and do not know about the bioeffects of nanoparticles: developing experimental approaches for safety assessment. Biomed. Microdevices. 2008. DOI 10.1007/s10544-008-9261-9.

14. Гусев А.И.Наноматериалы, наноструктуры, нанотехнологии. М.: Физматлит. 2007. 115 c. [Gusev A. I. Nanomaterials, nanostructures, nanotechnology. Moscow, Fizmatlit. 2007. 115 p. (inRuss.)]

15. Porter L.A., Jr., Ji D., Westcott S.I. et al. Gold and silver nanoparticles functionalized by the adsorption of dialkylsulfides. Langmuir. 1998. V.14. P.7378.

16. Zhang W., Quaio X., Chen J. Synthesis of silver nanoparticles Effects of concerned papameters in water/oil microemuIsion.//Materials Science and Engineering B. 2007. V.142.P.1.

17. Rinck P. A. Magnetic Resonance in Medicine. The Basic Textbook of the European Magnetic Resonance Forum. Oxford: Blackwell Scientific Publications, 1993. 246 c.

18.БарановД.А.,С.П.Губин.Магнитныенаночастицы:достижения ипроблемыхимического синтеза. Журнал «Радиоэлектроника. Наносистемы. Информаџионные технологии». 2009.т.1,№ 1-2. -C. 129-147. [BaranovD. A., S. P. Gubin. Magnetic nanoparticles: achievements and problems of chemical synthesis. Journal «Radioelectronics. Nanosystems. Information technology.» 2009.-vol. 1, No. 1-2. -S. 129-147. (in Russ.)]

19. ГубинС. П.,КокшаровЮ. А., ХомутовГ. Б. Магнитныенаночастицы: методыполучения, строениеисвойства. Журнал «Успехихимии». 2005. Т. 74, № 6. 539-574. [Gubin S. P., Koksharov Y. A., Khomutov G. B. Magnetic nanoparticles: methods of preparation, structure and properties. The journal "Successes of chemistry". 2005. T. 74, № 6. 539-574. (in Russ.)]

20. Hyeon T. Chemical synthesis of magnetic nanoparticles // Chem. Commun. 2003. Is. 8. P. 927-934.

21. Tartaj P., del Puerto Morales M., Veintemillas-Verdaguer S. et al. The preparation of magnetic nanoparticles for applications in biomedicine. // J. Phys. D: Appl. Phys. 2003. V. 36. P. R182-R197.

22. ТакетомиС.,ТикадзумиС. Магнитныежидкости. М.: Мир, 1993. 272 с. [Taketomi S., Chikazumi S. Magnetic fluids. Moscow, Mir, 1993. 272. (in Russ.)]

23. Tartaj P., del Puerto Morales M., Veintemillas-Verdaguer S. et al. The preparation of magnetic nanoparticles for applications in biomedicine. // J. Phys. D: Appl. Phys. 2003. V. 36. P. R182-R197. 
24. Lu A.-H., Salabas E. L., Schuth F. Magnetic Nanoparticles: Synthesis, Protection, Functionalization, and Application // Angew. Chem. Int. Ed. 2007. V.46. P. 1222-1244.

25. Buzea C., Pacheco Blandino I. I., Robbie K. Nanomaterials and nanoparticles: Sources and toxicity // Biointerphases. 2007. V. 2, Is. 4. P. MR17- MR172.

26. Зимина Т. М., Соловьев А. В., Лучинин В. В. Исследование магнитных наносуспензий биомедицинского применения. Журнал «Биотехносфера». 2011. № 1-2. 62-72. [ZiminaT. М., SolovievA. V., LuchininV. V. theStudyofthemagneticnanosuspension biomedical applications. The Magazine "Biotechnosphere". 2011. No. 1-2. 62-72 p. (in Russian)]

27. Hergt R., Dutz S., Muller R. et al. Magnetic particle hyperthermia: nanoparticle magnetism and materials development for cancer therapy // J. Phys.: Condens. Matter. 2006. V.18. P. S2919-S2934. 